\title{
The Normative STRucture of THE StaTe OF EPIDEMIC UNDER POLISH LAW
}

Accepted
18. 05. 2021
Revised
02. 08. 2021
Published
29. 10. 2021

Keywords state of epidemic, extraordinary measures, basic rights, Poland, COVID-19

\section{Leszek Bosek}

University of Warsaw, Faculty of Law and Administration, Civil Law Department and Center for Medical Law and Biotechnology, Warsaw, Poland.

E-mail: bosek@wpia.uw.edu.pl

CORRESPONDING AUTHOR bosek@wpia.uw.edu.pl 


\section{$1 \quad$ Introduction}

The social and economic impact of the COVID-19 crisis on the European Union cannot be denied. First, anti-epidemic emergency measures were launched pursuant to Article 122(2) of the Treaty on the Functioning of the European Union ${ }^{1}$; a new system of own resources of the Union was agreed upon by the Member States; ${ }^{2}$ a European Union Recovery Instrument to support the recovery in the aftermath of the COVID-19 crisis was established ${ }^{3}$; and, the Commission was empowered on an exceptional basis to borrow temporarily up to EUR 750.000 million and to provide loans and grants, both for the sole purpose of addressing the consequences of the COVID-19 crisis. ${ }^{4}$ Second, Member States launched various containment strategies such as social distancing measures, travel restrictions, quarantines and lockdowns on an emergency constitutional or statutory basis. Poland, as with France and Germany, confronted the crisis by instituting emergency measures based on ordinary law. Poland's Minister of Health announced a state of epidemic emergency on 13 March 2020 and a week later a state of epidemic on the basis of the Act of 5 December 2008 on preventing and combating infections and infectious diseases. ${ }^{5}$ Member States also launched various state aid programs in support of the containment measures. These programs were held to be both proportional and compatible with the exclusive competence of the EU on competition law. ${ }^{6}$

The purpose of this article is to present a concept and a normative structure of the state of epidemic, which is defined under Polish law as a legal situation introduced in a given area in connection with an epidemic in order to undertake anti-epidemic and preventive measures specified in the Act to minimize the effects of the epidemic. The state of epidemic will be analysed from a constitutional standpoint and will also

\footnotetext{
${ }^{1}$ Council Regulation (EU) 2020/672 of 19 May 2020 on the establishment of a European instrument for temporary support to mitigate unemployment risks in an emergency (SURE) following the COVID-19 outbreak, OJ L 159, pp. $1-7$.

2 See Council Decision (EU, Euratom) 2020/2053 of 14 December 2020 on the system of own resources of the European Union and repealing Decision 2014/335/EU, Euratom, Official Journal of the European Union L 424/1. ${ }^{3}$ See Council Regulation (EU) 2020/2094 of 14 December 2020 European Union Recovery Instrument to support the recovery in the aftermath of the COVID-19 crisis, Official Journal of the European Union, LI 433/23.

${ }^{4}$ See Article 5 and 6 of the Decision mentioned above (note 3).

${ }^{5}$ Ustawa o zapobieganiu oraz zwalczaniu zakażeń i chorób zakaźnych u ludzi, Journal of Laws 2020, position 1845, hereafter: "the Act".

${ }^{6}$ See: judgments of the General Court (Extended Composition) of: 17 February 2021, Ryanair v Commission, T259/20, para 26, ECLI:EU:T:2021:92; 17 February 2021 Ryanair v Commission, T-238/20, ECLI:EU:T:2021:91; 14 April 2021, T-378/20 Ryanair DAC/Commission, EU:T:2021:194; 14 April 2021, T-379/20 Ryanair DAC/Commission, EU:T:2021:194; Judgment of the Court 14 April 2021, Ryanair DAC v Commission, T-388/20, EU:T:2021:196.
} 
be compared with the relatively new French and German counterparts of 2020 - a nationwide state of epidemic.

\section{$2 \quad$ German and French models}

Germany responded to the crisis of 2020 with measures based on the Infection Protection Act of 2001. ${ }^{7}$ On the basis of the 2020 amendment of IfSG, the German Bundestag announced 'a nationwide state of epidemic' on 25 March 2020 (Para 5 (1) sentence 4 of IfSG "Epidemische Lage von nationaler Tragweite") and Bundesländern ordered quarantines (on the basis of Para 30 IfSG) and lockdowns (Schmitt, 2020) in the form of banning professional activities (Para 31 IfSG), closed care facilities for minors (Para 33 IfSG) and restricted or prohibited events or other gatherings of a large number of people or obliged persons not to leave the place where they were located or to enter designated places until necessary protective measures have been taken (Para 28 IfSG). As demonstrated in the literature, it is legitimate to empower the Parliament to announce a state of epidemic. However, this resulted in political assessments trumping medical and scientific judgments (Gärditz, 2020: 741-744, 741). An initial bill, changed later in the Parliament, proposed that the government, upon medical account, should be empowered to declare and repeal a state of epidemic (Gärditz, 2020: 741-744, 741).

Bundesverassungsgericht declared that IfSG constitutes a sufficient legal basis for imposing restrictions on the public during the pandemic (Dec. of 10.04.2020, Ref. No. 1 BvQ 30/20; see also Dec. of: 7.06.2021 r., Ref 1 BvR 1260/21; 5.05.2021 r., Ref. 1 BvR 781/21, 1 BvR 889/21, 1 BvR 854/21, 1 BvR 805/21) and that authorities are empowered to regulate in favour of the right to life and physical integrity, even when these restrictions conflict with other basic rights (Dec. of: 7.04.2020, Ref. No. 1 BvR 755/20; 10.04.2020, Ref. No. 1 BvQ 28/20). The Court held in particular that restrictions were only temporary (Verwaltungsgericht in Hannover, judgment of 27.03.2020, Ref. No. 15 B 1968/20) and that there were alternative forms of realisation of basic rights in a given context (Verwaltungsgericht in Dresden, judgment of 30.03.2020, Ref. No. 6 L 212/20). However, on 29 April 2020 the Constitutional Court ruled that the exercise of freedom of religion should be

\footnotetext{
${ }^{7}$ Act of 20.07.2000 on preventing and combating infectious diseases [Gesetz zur Verhütung und Bekämpfung von Infektionskrankheiten beim Menschen], Journal of Laws I (2020) 104, hereafter: "IfSG".
} 
permitted despite the pandemic, provided that proper sanitary precautions were guaranteed (Dec. of 29.04.2020, Ref. No. 1 BvQ 44/20).

It can be inferred from the German case law that the constitutional emergency powers as regulated in Article 91 of the Basic Law were not necessary and that the public authorities should be granted wide discretion when deciding what should be done to respond to the epidemic crisis.

France also responded to the epidemic of 2020 by imposing nationwide confinement, introduced on the basis of blanket Article L 3131-1 of the Public Health Code and the doctrine of exceptional circumstances (Heyriès and Dames Dol et Laurent, nº3412, CE 28.06.1918; Dames Dol et Laurent, CE, 28.02.1919, nº1593. See Sizaire, Un colosse aux pieds d'argile. Les fondements juridiques fragiles de l'urgence sanitaire, La Revue des droits de l'homme 2 (2020), pp. 1-10; Hourson S., 'Aux confins du confinement', Droit admnistratif 5, 2020: 3). Article L 3131-1 of the Public Health Code empowers executives to undertake sall anti-epidemic measures, including individual ones«. In the event of a serious health threat requiring emergency measures, in particular in the event of a threat of an epidemic, the Minister responsible for health may, by reasoned decree, prescribe in the interest of public health "any measure" proportionate to the risks incurred and appropriate to the circumstances of time and place in order to prevent and limit the consequences of possible threats to the health of the population (https://www.legifrance.gouv.fr/codes/section_lc/LEGITEXT000006072665/L EGISCTA000006171181/\#LEGISCTA000041748550 [access 9.09.2021].).

Neither the "state of siege" provision contained in Article 36 of the Constitution nor the emergency clause contained in Article 16 of the Constitution, conferring "exceptional powers" upon the President in times of "serious and immediate threat to the public institutions," were applied to combat COVID-19 (Bosek, 2021a: 126, 140).

The Conseil d'Etat ruled that a total lockdown is not legally authorised (Syndicat des jeunes médecins, No 439674, CE 22 March 2020), terminated the general ban on gatherings in places of worship (Association Civitas, No 440361, 440511, CE 18 May2020), stopped the surveillance of Paris's population by drones (Association de la quadrature du net, Ligue des droits de l'homme, No 440442, 440445, CE 18 May 2020), prohibited the use of thermal cameras in schools in the absence of appropriate 
personal data management measures (Ligue des droits de l'bomme, No 441065, CE 26 June 2020), held that demonstrations with more than ten (but fewer than 5,000) participants were legal as long as certain organizational requirements were met (i.e. prior notification to the public authorities) and public health measures respected (Ligue des droits de l'homme, CGT-Travail et autres, No 440846, 440856, 441015, CE 13 June 2020) (Ligue des droits de l'homme, CGT-Travail et autres, No 440846, 440856, 441015, CE 13 June 2020). Moreover, the Constitutional Council held that individuals could not be required to observe preventive quarantine for more than 12 hours per day for more than 14 days without the prior authorization of a court, as more restrictive provisions would violate the individual's right to liberty (Décision $n^{\circ} 2020-800$ DC, 11.05.2020, 43).

\section{The constitutional perspective}

Chapter XI of the Constitution of the Republic of Poland of 1997 established a complex regulation under the heading 'extraordinary measures', including a principle of a closed catalogue of constitutional extraordinary regimes (Brzeziński, 2007; Prokop, 2005; Radziewicz, 2019: 654): a state of martial law, a state of emergency and a state of natural disaster.

Currently, nine out of every ten countries across the globe have emergency provisions written into their constitutions (Bjørnskov \& Voigt, 2018: 101) and onethird list natural disasters as a separate basis for issuing a declaration of emergency (Bjørnskov \& Voigt, 2018: 101).

A natural disaster may be declared under the constitution in order to combat the spread of infectious diseases (Steinborn, 2016: 1626; Działocha, 2005a: 2). Article 3(1) point 2 of the Act of 18 April 2002 on the state of natural disaster (Journal of Laws 2017, item 1897) included an epidemic within the category of natural catastrophes within the meaning of Article 232 of the Constitution.

The Council of Ministers may introduce a state of natural disaster for a definite period, but not exceeding 30 days, covering a part or the whole territory of the State. The proclamation must be published in the Journal of Laws of the Republic of Poland, and also made public through an announcement by the competent voivode by posting in public places, as well as in a manner customarily adopted in a given area. An extension of a state of natural disaster may be made with the consent of the 
Parliament (Sejm). Refusal of the consent obligates the Council of Ministers to abolish a state of natural disaster before the expiry of the time into which it was introduced.

The Council of Ministers may introduce a state of natural disaster on its own initiative or at the request of the competent voivode by way of a regulation. The regulation should specify the reasons underpinning it, the date of introduction, as well as the area and duration of the state of natural disaster, and the types of necessary restrictions on human and civil rights and freedoms. However, the Council of Ministers is bound neither by the Constitution, nor by the regulation, to rely on the medical account or medical advice.

The Constitution, together with the Act of 2002 on the state of natural disaster, empowers the Council of Ministers, among others, to order the suspension of the activities of certain entrepreneurs (Article 21(1)(1) of the Act); to prohibit specific types of business activities (Article 21(1)(2) of the Act); to obligate persons to undergo medical examinations, treatment, preventive vaccinations and other measures, preventive measures and treatments necessary to combat infectious diseases and the effects of chemical and radioactive contamination (Article 21(1)(5) of the Act); and, to obligate persons to submit to quarantine (Article 21(1)(6) of the Act). However, neither the Constitution nor the Act stipulates any specific rules concerning how these measures should be ordered.

The statutory model of anti-epidemic emergency powers relies on a different constitutional basis. This model is authorized by Article 68(4) of the Constitution as an important constituent element of a complex regulation of the basic right to health. It states that public authorities shall combat epidemic illnesses and prevent the negative health consequences of degradation of the environment. Despite different views on the precise scope of application of this provision (MiaskowskaDaszkiewicz, 2017: 69-71; Bosek, 2016: 1523-1565), there is no doubt that it requires the introduction of a statutory scheme to combat infections and infectious diseases (Janik, 2015: 105; Pałka, 2018: 601-624; see also Bosek \& Roszkiewicz, 2020: 201281). Article 68(4) is located in Chapter II of the Constitution, which is devoted to basic human rights, and not in the chapter XI of the Constitution, which lists three extraordinary emergency regimes. Thus, the statutory anti-epidemic model is not authorised by Article 232 of the Constitution. 
The Constitutional Court has ruled to allow statutory regimes regulating „crisis situations" that are separate from the constitutional extraordinary regimes and that fall within the normal functioning of the State (Judgments of: 3.07.2012, No. K $22 / 09$ and 21.04.2009, No. K 50/07), even if there is no Constitutional basis for them that would be comparable with Article 68(4). According to the Constitutional Court, regulations of extraordinary measures in the Constitution cannot be interpreted expansively.

Moreover, Article 218(1) of the Constitution delimits attribution of powers in crisis situations on the basis of the principle of proportionality (Wiśniewski, 1997: 152; Wołpiuk, 2002: 101; Wojtyczek, 1999: 250-251). According to this provision, the Council of Ministers is empowered "in situations of particular danger" to introduce appropriate constitutional extraordinary measures "if ordinary constitutional measures are inadequate". Therefore, if in a situation of particular danger, the statutory State of Epidemic or the State of Epidemic Emergency is sufficient to combat an epidemic, it is not necessary to declare the constitutional state of natural disaster. The Council of Ministers is given wide discretion and "the last word" to determine what circumstances constitute a "particular danger" under Article 218(1).

The Supreme Court confirmed this interpretation and explained that "the Council of Ministers was not obliged to introduce a state of natural disaster in response to the COVID-19 epidemic, in a situation where it was possible to introduce the State of Epidemic Emergency or the State of Epidemic, as provided for in Article 46 of the Act of 5 December 2008 on preventing and combating infections and infectious diseases. The decision to introduce the state of natural disaster, due to the general conditions for its introduction [Article 228 of the Constitution], belongs to the sphere of administrative discretion of state authorities, which means that it is up to them to assess whether these conditions have been met in a specific situation" (Decision of the Supreme Court of 28.07.2020, I NSW 2849/20).

Article 233 of the Constitution constitutes an important constituent element of the regulation of anti-epidemic measures. It defines rights and freedoms which may be limited (the Constitution does not derogate nor suspend any right in emergency) in the constitutional emergency. Section 1 of the Article enumerates rights and freedoms which can never be restricted, not even under martial law: the dignity of the person, citizenship, protection of life, humane treatment, ascription of criminal responsibility, access to a court, personal interests, conscience and religion, family 
and children rights (Bosek, 2012: 102-104). Article 233, section 3, specifies rights and freedoms which may be restricted in the state of a natural disaster: freedom of economic activity, personal freedom, inviolability of the home, freedom of movement and sojourn on the territory of the Republic of Poland, the right to strike, the right of ownership, freedom to work, the right to safe and hygienic conditions of work and the right to rest. Article 233(3) suggests a contrario that, for example, freedom of peaceful gatherings may not be restricted. Bearing in mind that restrictions on gatherings in public and private are essential anti-epidemic measures, it is easy to understand why a natural disaster regime is the best to combat epidemics.

Article 233 is not applicable to the statutory state of epidemic. It seems, therefore, that the situation is a bit clearer with normative regulations pertaining to social distancing and gatherings. It seems obvious that the whole anti-epidemic prevention strategy, in democratic states, relies on social distancing and bans on gatherings.

Moreover, an important constituent element of the constitutional model of antiepidemic emergency is the express exclusion of any changes to the Constitution or rules underpinning democratic processes during a period of introduction of extraordinary regimes. The Acts on Elections to the Sejm, the Senate and organs of local government, the Act on Elections to the Presidency, as well as statutes on extraordinary measures shall not be subject to change (Article 228(5) of the Constitution). During a period of introduction of extraordinary measures, as well as within the period of 90 days following their termination, the term of office of the Sejm may not be shortened, nor may a nationwide referendum, nor elections to the Sejm, Senate, organs of local government nor elections for the Presidency be held, and the term of office of such organs shall be appropriately prolonged. Elections to organs of local government shall be possible only in those places where the extraordinary measures have not been introduced (Działocha, 2005b: 17).

This constitutional principle is not applicable during a period of introduction of the State of Epidemic or the State of Epidemic Emergency (Resolution of the Supreme Court of 3.08.2020, I NSW 5890/20). The constitutional principle may not be used to extend a scope of application of norms of exception. However, the constitutional principles of legal certainty and stability of electoral laws do not allow adoption of laws that would change important electoral regulations six months before an election, except in ,extraordinary circumstances of objective character” (Judgments of the Constitutional Tribunal of: 3.11.2006, K 31/06; 28.10.2009, Kp 3/09; 
20.07.2011 r., K 9/11; resolution of the Supreme Court of 3.08.2020, I NSW $5890 / 20)$. Executive legislation in this respect is excluded per se. ${ }^{8}$

\section{Statutory regulation of the state of epidemic}

Since 1919, Polish anti-epidemic emergency measures, developed under the relevant acts of 1919, 1935, 1963 (Bosek, 2021b: 9-39, 88-114, 743-838), were based on a normative model of only individual sanitary (administrative) acts issued by local authorities. The Act of 6 September 2001 on infectious diseases and infections (Journal of Laws from 2001, item 1384) was the first anti-epidemic law implementing the obligation to combat epidemic diseases laid down in Article 68(4) of the Constitution of the Republic of Poland of 2 April 1997 (Journal of Laws from 1997, item 483 with amendments) which adjusted the model to social and epidemiological reality. For the first time, it introduced into Polish Law an institution of a state of epidemic as the key extraordinary sanitary measure.

The very core of this model was a quantum of statutory authorisations to the executive to launch regulations ordering or banning activities to prevent and combat epidemic diseases. Restrictions could be introduced under Article 33 of the Act by executive regulations of the voivode ${ }^{9}$ for the territory of a region or the Minister of Health for a nationwide epidemic.

The binding Act of 2008 preserved the model of anti-epidemic measures developed under the Act of 2001 and provided a legal basis for administrative and normative sanitary measures. The Act provides a balance between the need for efficient response to the rapidly changing epidemic realities and the need to protect lives and human rights. The Act neither suspends human rights nor - as a matter of principle - restricts them directly, but authorises the Minister of Health or the Council of

\footnotetext{
${ }^{8}$ See judgment of Regional Administrative Court in Warsaw of 15 September 2020, Ref. No. VII SA/Wa 992/20, invalidating the Prime Minister's decision ordering the Polish postal office to organize presidential elections by correspondence 'in connection with counteracting COVID-19'. The court found that the Prime Minister had given the order at a time when the Election Code entrusted the authority to organize elections to the National Electoral Commission. The Prime Minister could not change the binding law by issuing an order. Broader context see: European Parliament resolution of 17 April 2020 on EU coordinated action to combat the COVID-19 pandemic and its consequences (2020/2616(RSP), in particular point 46.

${ }^{9}$ Voivode is according to the Article 152 Constitution a representative of the government in a region.
} 
Ministers in strictly defined areas to establish restrictions. Before the SARS-CoV-2 crisis a state of epidemic was never announced ${ }^{10}$.

The core of the binding model is the list of anti-epidemic emergency powers enshrined in Article 46 of the Act, opening Chapter 8 of the Act headed "Principles of conduct with the state of epidemic emergency and the state of epidemic". Article 46 provides a comprehensive regulation of the legal framework of two specific normative regimes: the State of Epidemic and the State of Epidemic Emergency. Article 46(1)1 authorizes the voivode, and Article 46(2) the minister responsible for health, to announce (and also repeal) by a regulation (ordinance) the State of Epidemic Emergency or the State of Epidemic, respectively in a province, several provinces or the entire country.

An epidemic is the necessary precondition required to declare the State of Epidemic Emergency and the State of Epidemic. An epidemic is defined by Article 2 point 9 of the Act as the occurrence in a given area of infections or cases of an infectious disease significantly larger than in the previous period, or the occurrence of infections or infectious diseases that did not occur so far. The Act does not define the previous period nor a quantity or a quality of infections required to declare the State of Epidemic Emergency or the State of Epidemic. Neither does the Act require an external declaration of pandemic by the WHO. It is clear that such wide definition is not correct. Correct definition of epidemic should stress mortality, for example to distinguish periodic »flu epidemic« from »deadly epidemic«. It seems that epidemic shoud be construed as a kind of »a public emergency threatening the life of the nation « in the meaning of Article 15 of the European Convention of Human Rights and Basic Freedoms.

There are two formal requirements: a request by a regional state sanitary inspector (in case of a local epidemic announced by a voivode) or a request by the Chief Sanitary Inspector (in case of a nationwide epidemic announced by the Minister of Health) and infections of the category recognised by the Act. The principle underpinning the 2008 Act is that enforcement of the Act is allowed only with respect to 50 diseases enumerated in an annex $\mathrm{Nr} 1$ to the Act.

\footnotetext{
${ }^{10}$ It was only once when in the West Pomeranian region a state of epidemic emergency was announced by the voivode. See an ordinance of the West Pomeranian Voivode of April 6, 2009, which declared the state of epidemic emergency because of invasive meningococcal disease in the city and commune of Goleniów and the commune of Przybierów and ordering vaccinations of children over 6 years of age (Journal of Laws of the West Pomeranian Voivodeship of 2009, No. 11, item 459).
} 
Article 2 point 23 defines the State of Epidemic Emergency as a legal situation introduced in a given area in connection with the risk of an epidemic and in order to undertake preventive measures specified in the Act. Article 2 point 22 defines the State of Epidemic as a legal situation introduced in a given area in connection with an epidemic in order to undertake anti-epidemic and preventive measures specified in the Act to minimize the effects of the epidemic.

While the Act defines both normative regimes, their distinctive normative features and axiological consistency, related to the content of the introduced restrictions, orders and bans in the area designated in a given regulation, can only be reconstructed from the provisions of Article 46. The provisions of Article 46(3), (4) and (5) authorize the Ministry of Health or voivodes to complete the State of Epidemic Emergency or the State of Epidemic with normative content, i.e. impose obligations by means of regulations (ordinances) on institutions and private persons staying in the territory of the Republic of Poland. This is because of the need to adjust emergency measures to rapid changes of epidemiological factors. Thus, a specific feature of the Polish model is that the anti-epidemic emergency regimes are mainly of a normative character and not administrative.

Regulations of the Minister of Health or voivode may lay down a temporary restriction of a specific method of movement, a temporary restriction or prohibition of the marketing and use of certain items or food products, a temporary restriction of the functioning of certain institutions or workplaces, a prohibition of organizing shows and other gatherings of people, an obligation to perform specific sanitary procedures, if their performance involves the functioning of certain production, service, commercial or other facilities, an order to provide real estate, premises, land and provide means of transport for anti-epidemic activities provided for by antiepidemic plans, the obligation to carry out preventive vaccinations and the groups of persons subject to these vaccinations.

Under the amendment to the Act of 2 March 2020, extraordinary regulatory powers were given also to the Council of Ministers, in practice reducing the role of the Ministry of Health in managing the crisis (Journal of Laws from 2020, item 1842 with amendments). According to Article 46a of the Act, the Council of Ministers is currently authorised in the event of the State of Epidemic or the State of Epidemic Emergency of the nature and dimensions exceeding the capacity of the competent governmental bodies and local governments, to determine, by regulation, on the 
basis of data provided by the minister responsible for health, the minister responsible for internal affairs, the minister responsible for public administration, Chief Sanitary Inspector and voivodes "the endangered area along with an indication of the type of zone in which the state of epidemic or the state of epidemic emergency occurred" and "the type of solutions used in the scope specified in Article 46b".

The scope of normative powers vested in the Council of Ministers is specified in Article 46b of the Act. The Council of Ministers may legislate in all areas, whereas the Minister of Health is empowered not only to legislate (as indicated in Article 46 of the Act) but also to order temporary limitations on certain aspects of business activity, temporary regulations of supplies for a specific type of articles, medical examinations and the use of other preventive measures and treatments by persons either known or suspected to be ill, the obligation to undergo quarantine, the place of quarantine, the temporary limitation of the use of sites or areas and the obligation to secure them, an evacuation order at specified times of specific places, areas and objects, an order or prohibition of staying in specific places and objects and in specific areas, the prohibition on leaving the zero zone by persons who are either known nor suspected of being ill, and, orders to move in a specific manner.

The broad scope of this statutory delegation of powers to executives may be criticised. Although constitutions containing provisions regarding emergencies iniformly leave significant discretionary power to the executive during broadly defined states of emergency (Bjørnskov \& Voigt, 2018: 114), the delegation of legislative powers to executives in ordinary circumstances should be strictly defined in an act of parliament (Article 92 of the Constitution). Nevertheless the level of precision of the Polish anti-epidemic statutory delegations of powers is much higher than that in emergency constitutions or in the French or German statutes.

Moreover, the anti-epidemic statutory delegations of powers are backed by Article 5 of the Act. Article 5 of the Act directly obliges everyone in the territory of the Republic of Poland to meet the general obligations: undergo sanitary procedures, preventive vaccinations, sanitary and epidemiological examinations, epidemiological supervision, quarantine, treatment, hospitalization, isolation, isolation at home, postexposure prophylactic use of drugs, providing information necessary for supervision epidemiological; it also imposes on the infected people with an infectious disease (carriers in the meaning of the Act) and ill persons the obligation to refrain from 
performing any work which may transmit an infection or an infectious disease to other people.

Although Article 5 establishes these obligations, each time requiring their reconstruction and application "on the principles set out in the Act", it aims at establishing common and exhaustively listed statutory obligations of persons staying in the territory of the Republic of Poland. There is no doubt that it determines their statutory nature. Their source is the Act itself. Consequently, Article 5 ensures the internal axiological and constructive coherence of the Act and the Constitution. The failure to explicitly establish the obligations of private persons in this Article would raise a fundamental doubt whether encroachments upon basic rights by executive regulations would be permissible (Cf. Articles 2, 31(3) of the Constitution).

Article 46(5) and (6) define the formal conditions for the entry into force of regulations announcing the State of Epidemic Emergency or the State of Epidemic: a promulgation in the relevant official journal (regulations of the Minister of Health and Council of Ministers must be published only in Journal of Laws, voivode only in regional journals). They also require the voivode to inform the public about the obligations arising from the announcement of State of Epidemic Emergency or State of Epidemic in a manner customarily adopted in the voivodeship.

A specific feature of the Polish anti-epidemic emergency model is that it is based on two different regimes: the State of Epidemic and the State of Epidemic Emergency. However, as indicated above, neither the quantity nor the quality of infections in a given area is defined and therefore also "the risk of an epidemic" as a precondition of the state of epidemic emergency is not defined. Both definitions refer to a notion of an epidemic defined in Article 2 point 9 of the Act. It is also clear that the State of Epidemic Emergency cannot be announced only on the basis of a potential risk, especially taking into account blanket definition of epidemic. A mere potential risk of an epidemic is not sufficient for imposing farreaching restrictions of basic rights nor is it justification for circumventing the principle of the separation of powers (Bjørnskov \& Voigt, 2018: 108). The Act must be interpreted in the light of the Constitution. Moreover, emergency powers in the State of Epidemic Emergency and the State of Epidemic attributed to the executives, as well as the nature and legal effects of restrictions are identical. Therefore, de lege ferenda only the State of Epidemic should remain. 
The Parliament is not empowered to declare, to approve, or to repeal a nationwide state of epidemic - these powers are vested exclusively in the Minister of Health. The Parliament (Sejm), empowered under the Constitution to political control of the government, to monitor the use of constitutional emergency powers, to investigate abuses, to extend these powers if necessary, and to suspend them if the emergency ends, may only force the Minister of Health and the whole Council of Minister to resign.

Consistent with a European trend, the power to monitor the legality of actions under statutory anti-epidemic emergency regimes is given to the judicial branch. However, the legal basis for a direct action to annul emergency measures is limited. Article 63(1) of the Governmental Administration in Voivodship Act (GAVA) only allows for challenges of regulations enacted by the voivode to be lodged before an administrative court. The provision of Article $63 \mathrm{sec} .1$ of the GAVA is aimed at the protection of the complainant's subjective rights and the mere objective contradiction of the Act with the law does not provide sufficient grounds for lodging a complaint (Judgment of Supreme Administrative Court of 30 January 2020 No. II OSK 3574/18). Regulations either of the Ministry of Health or of the Council of Ministers can be reviewed only incidentally by courts in criminal or civil proceedings or by administrative courts (the jurisprudence emphasizes that if the court refuses to apply the provisions of a sub-statutory act, it "should independently conduct a detailed legal analysis") (Judgment of the Supreme Court 5 February 2008, Act call No. II PK 150/07).

This restriction is of systemic character. Constitutional review of ministerial and governmental regulations is performed by the Constitutional Tribunal. Statutes and regulations may be challenged by way of a constitutional complaint, but only if rights or freedoms of an individual have been violated by a specific decision or ruling, which was based on an unconstitutional provision (Article 79 of the Constitution). Statues and regulations can also by questioned in a procedure of preliminary question to the Constitutional Tribunal by a court, provided that the answer to such a question will determine a decision of this court (Article 193 of the Constitution). 
Moreover, according to the case law of the Constitutional Tribunal on martial law (Judgment of the Constitutional Tribunal of 16.3.2011 r., K 35/08) it is unlikely that the announcement of the state of emergency or the state of epidemic will be effectively controlled. ${ }^{11}$ This is because of the very nature of a declaration of either a state of emergency or epidemic, which is not a norm but rather an individual act focussed on a given emergency or epidemic. However, other elements of the governmental regulations, in particular provisions imposing restrictions as "normative acts", can be constitutionally reviewed.

Judicial review encompasses sanctions imposed by public authorities for noncompliance with sanitary restrictions. Both the Supreme Court and ordinary courts control fines imposed by the police, and case-law has confirmed that those fines imposed for disregarding the obligation to wear masks or prohibiting leaving the house at the beginning of the epidemic are illegal, because they were established in a regulation that was issued in violation of statutory delegation, which did not authorise the Minister of Health to establish such an obligation. ${ }^{12}$ In turn, administrative courts hear complaints against decisions of sanitary inspection imposing fines for violating sanitary regulations. ${ }^{13}$

It seems that judicial review of emergency powers is convincingly considered as a constitutional standard to protect the rights of citizens (Jackson, 2004: 368-369). Even when operating in emergency, it is possible to ensure that basic rule-of-law values are preserved (Dyzenhaus, 2004: 269-270).

\section{$5 \quad$ Conclusions}

The state of epidemic is the key anti-epidemic emergency measure under Polish law. It was introduced over 20 years ago and is authorized directly by the Constitution. The announcement of the State of Epidemic in 2020 was justified by a declaration of the COVID-19 pandemic by the WHO and the fact that the SARS-CoV-2 crisis

\footnotetext{
${ }^{11}$ However, it is postulated in a legal literature: Bosek, 2021b: 767-70.

12 See judgment of Supreme Court of 16 March 2021, II KK 97/21, www.sn.pl; judgment of Supreme Court of 16 March 2021, II KK 74/21, www.sn.pl; Judgment of Supreme Court of the Republic of Poland of 16 March 2021, II KK 64/21, www.sn.pl. See also decisions of District Court in Kościan of 8 June 2020, Ref. No. II W 71/20; district Court in Siedlce of 29 September 2020, Ref. No. II W 924/20; District Court in Nysa of 9 November 2020, Ref. No. II W 981/20.

13 Judgment of Regional Administrative Court in Gliwice of 20 September 2020, Ref. No. III SA/Gl 540/20; judgment of Regional Administrative Court in Gorzów Wielkopolski of 23 September 2020, Ref. No. II SA/Go 332/20; judgment of Regional Administrative Court in Białystok of 22 October 2020, Ref. No. II SA/Bk 528/20.
} 
was not of sufficient magnitude to warrant the invocation of constitutional emergency powers. France, Germany and Poland all chose to deal with the COVID19 crisis by delegating powers to the executive by ordinary legislative means.

The core of the normative structure of this institute is a broadly drafted statutory authorisation for executive legislation. The case law under review demonstrates that the broad legal basis is necessary to protect lives, mitigate natural hazards of infectious diseases and counteract epidemics. This is consistent with a clear longterm trend to allocate more, rather than less, powers to the executive during times of emergency (Bjørnskov \& Voigt, 2018: 125). The analysis of Polish case law demonstrates that certain restrictions introduced by the executive, in particularly those as intrusive as the ban on leaving one's house, were not sufficiently or comprehensively authorised by the Parliament. Parliamentary supervision of the executive's use of the authority vested therein, exercised in principle by political control over the government and by virtue of new laws, is necessary and justified by the principle of separation of powers, but not sufficient. Rather, Parliament's oversight actions must be supplemented by judicial revies of the executive legislation.

The declaration of the state of epidemic does not provide the executive with a carte blanche to trample upon basic rights and infringe on the democratic process and norms.

\section{Acknowlegment}

This article is based on the paper presented on the Conference "Responses to COVID crisis in Central and Eastern European Countries. New Frontiers of Health Law", Institute of Social Sciences, Belgrade (Serbia) on 18 March 2021. It is a revised and updated version of a study Anti-Epidemic Emergency Regimes under Polish Law in Comparative, Historical and Jurisprudential Perspective, European Journal of Health Law 28 (2021) 113-141, doi:10.1163/15718093-bja10039.

\section{Legislation, Acts, Regulations and Court Decisions}

Act of 20 July 2000 on preventing and combating infectious diseases [Gesetz zur Verhütung und Bekämpfung von Infektionskrankheiten beim Menschen], Journal of Laws I (2020) 104, "IfSG".

Act of 5 December 2008 on preventing and combating infections and infectious diseases [Ustawa o zapobieganiu oraz zwalczaniu zakażeń i chorób zakaźnych u ludzi] Journal of Laws 2020, position 1845, "the Act".

Code de la santé publique, 
https://www.legifrance.gouv.fr/codes/section_lc/LEGITEXT000006072665/LEGISCTA0 00006171181/\#LEGISCTA000041748550 [access 9.09.2021]

Constitutional Council (France) Décision of 11 May 2020, n² 2020-800 DC, Décision n 2020-800 DC du 11 mai 2020, Conseil constitutionnel (conseil-constitutionnel.fr).

Constitutional Tribunal of the Republic of Poland, judgment of 16 March 2011 r., K 35/08. https://ipo.trybunal.gov.pl/.

Constitutional Tribunal of the Republic of Poland, judgment of 20 July 2011 r., K 9/11. https://ipo.trybunal.gov.pl/.

Constitutional Tribunal of the Republic of Poland, judgment of 21 April 2009, No. K 50/07. https://ipo.trybunal.gov.pl/.

Constitutional Tribunal of the Republic of Poland, judgment of 28 October 2009, Kp 3/09. https://ipo.trybunal.gov.pl/.

Constitutional Tribunal of the Republic of Poland, judgment of 3 July 2012, No. K 22/09. https://ipo.trybunal.gov.pl/.

Constitutional Tribunal of the Republic of Poland, judgment of 3 November 2006, K 31/06https://ipo.trybunal.gov.pl/

Council of the State (CE, France) Association Civitas, No 440361, 440511, 18 May 2020. https://www.conseil-etat.fr

Council of the State (CE, France) Association de la quadrature du net, Ligue des droits de l'bomme, No 440442, 440445, 18 May 2020. https://www.conseil-etat.fr

Council of the State (CE, France) Dames Dol et Laurent, 28 February 1919, n61593. https://www.conseil-etat.fr

Council of the State (CE, France) Heyriès and Dames Dol et Laurent, 28 June 1918; No. 63412. https://www.conseil-etat.fr

Council of the State (CE, France) Ligue des droits de l'homme, 26 June 2020; No 441065. https://www.conseil-etat.fr

Council of the State (CE, France) Ligue des droits de l'homme, CGT-Travail et autres, 13 June 2020; No 440846, 440856, 441015. https://www.conseil-etat.fr

Council of the State (CE, France) Syndicat des jeunes médecins, 22 March 2020; No 439674. https://www.conseil-etat.fr

Council Regulation (EU) 2020/672 of 19 May 2020 on the establishment of a European instrument for temporary support to mitigate unemployment risks in an emergency (SURE) following the COVID-19 outbreak, OJ L 159, pp. 1-7.

Council Decision (EU, Euratom) 2020/2053 of 14 December 2020 on the system of own resources of the European Union and repealing Decision 2014/335/EU, Euratom, Official Journal of the European Union L 424/1.

Council Regulation (EU) 2020/2094 of 14 December 2020 European Union Recovery Instrument to support the recovery in the aftermath of the COVID-19 crisis, Official Journal of the European Union, LI 433/23.

District Court in Kościan, decision of 8 June 2020, Ref. No. II W 71/20.

District Court in Nysa, decision of 9 November 2020, Ref. No. II W 981/20.

District Court in Siedlce, decision of 29 September 2020, Ref. No. II W 924/20.

European Parliament resolution of 17 April 2020 on EU coordinated action to combat the COVID19 pandemic and its consequences (2020/2616(RSP).

Federal Constitution Court (Germany), decision of 7 April 2020, Ref. No. 1 BvR 755/20.

"https://www.bundesverfassungsgericht.de.

Federal Constitution Court (Germany), decision of 10 April 2020, Ref. No. 1 BvQ 30/20.

"https://www.bundesverfassungsgericht.de

Federal Constitution Court (Germany), decision of 10 April 2020, Ref. No. 1 BvQ 28/20.

"https://www.bundesverfassungsgericht.de.

Federal Constitution Court (Germany), decision of 29 April 2020, Ref. No. 1 BvQ 44/20.

"https://www.bundesverfassungsgericht.de.

Federal Constitution Court (Germany), decision of 5 May 2021 r., Ref. 1 BvR 781/21, 1 BvR 889/21,

1 BvR 854/21, 1 BvR 805/21. https://www.bundesverfassungsgericht.de 
Federal Constitution Court (Germany), decision of 7 June 2021 r., Ref 1 BvR 1260/21. https://www.bundesverfassungsgericht.de

General Court (Extended Composition), judgment of 17 February 2021, Ryanair v Commission, T259/20, para 26, ECLI:EU:T:2021:92.

General Court (Extended Composition), judgment of 14 April 2021, T-378/20 Ryanair DAC/Commission, EU:T:2021:194.

General Court (Extended Composition), judgment of 14 April 2021, Ryanair DAC v Commission, T388/20, EU:T:2021:196.

General Court (Extended Composition), judgment of 17 February 2021 Ryanair v Commission, T-238/20, ECLI:EU:T:2021:91.

Journal of Laws 2017, item 1897, Poland.

Journal of Laws from 1997, item 483 with amendments, Poland.

Journal of Laws from 2001, item 1384, Poland.

Journal of Laws from 2020, item 1842 with amendments, Poland.

Journal of Laws of the West Pomeranian Voivodeship of 2009, No. 11, item 459, Poland.

Regional Administrative Court in Białystok, judgment of 22 October 2020, Ref. No. II SA/Bk 528/20. https://orzeczenia.nsa.gov.pl/.

Regional Administrative Court in Gliwice, judgment of 20 September 2020, Ref. No. III SA/Gl 540/20. https://orzeczenia.nsa.gov.pl/

Regional Administrative Court in Gorzów Wielkopolski, judgment of 23 September 2020, Ref. No. II SA/Go 332/20. https://orzeczenia.nsa.gov.pl/.

Regional Administrative Court in Warsaw, judgment of 15 September 2020, Ref. No. VII SA/Wa 992/20. https://orzeczenia.nsa.gov.pl/.

Supreme Administrative Court of the Republic of Poland, judgment of 30 January 2020 No. II OSK 3574/18. https://orzeczenia.nsa.gov.pl/.

Supreme Court of the Republic of Poland, decision of 28 July 2020, I NSW 2849/20. www.sn.pl.

Supreme Court of the Republic of Poland, judgment of 16 March 2021, II KK 97/21. www.sn.pl.

Supreme Court of the Republic of Poland, judgment of 16 March 2021, II KK 74/21. www.sn.pl.

Supreme Court of the Republic of Poland, judgment of 16 March 2021, II KK 64/21. www.sn.pl.

Supreme Court of the Republic of Poland, judgment of 5 February 2008, II PK 150/07. www.sn.pl.

Supreme Court of the Republic of Poland, resolution of 3 August 2020, I NSW 5890/20. www.sn.pl.

Verwaltungsgericht in Hannover, judgement of 27 March 2020, Ref. No. 15 B 1968/20. "https://dejure.org

Verwaltungsgericht in Dresden, judgment of 30 March 2020, Ref. No. 6 L 212/20. https://dejure.org

\section{References}

Bjørnskov, C. \& Voigt, S. (2018) The architecture of emergency constitutions, International Journal of Constitutional Law, 16(1), pp. 101-127, doi: 10.1093/icon/moy012.

Bosek, L. \& Roszkiewicz, J. (2020) Konstytucyjne uwarunkowania systemu udzielania świadczeń zdrowotnych, In: Safjan, M. \& Bosek, L. (eds.) System Prawa Medycznego, vol. 3 (Warsaw: C.H. Beck), pp. 201-281.

Bosek, L. (2012) Gwarancje godności ludzkiej i ich wpływ na polskie prawo cywilne (Warsaw: Wydawnictwo Sejmowe), pp. 102-104.

Bosek, L. (2016) In: Safjan, M. \& Bosek L. (eds.) Konstytucja Rzecsypospolitej Polskiej. Komentarz, vol. I, (Warsaw: C.H. Beck), pp. 1523-1565.

Bosek, L. (2021a) Anti-Epidemic Emergency Regimes under Polish Law in Comparative, Historical and Jurisprudential Perspective, European Journal of Health Law, 28, pp. 113-141, doi: 10.1163/15718093-bja10039.

Bosek, L. (2021b) In: Bosek L. (ed.), Ustawa o zapobieganiu oraz zwalczaniu zakażeń i chorób zakaźnych u ludzi. Komentarz (Warsaw: C.H. Beck), pp. 9-39, 88-114, 743-838.

Brzeziński, M. (2007) Stany nadzrnyczajne w polskich konstytucjach (Warsaw: Wydawnictwo Sejmowe), p. 170. 
Dyzenhaus, D. (2004) Intimations of legality amid the clash of arms, International Journal of Constitutional Law, 2(2), pp. 244-271.

Działocha, K. (2005a) In: Garlicki, L. (ed.) Konstytucja Rzecrypospolitej Polskiej. Komentary, vol. IV (Warszawa: Wydawnictwo Sejmowe), comment to Art. 232, p. 2.

Działocha, K. (2005b) In: Garlicki, L. (ed.) Konstytucja Rzecrypospolitej Polskiej. Komentarz, vol. 4 (Warsaw: Wydawnictwo Sejmowe), commentary to Art. 228, 17.

Gärditz, K.F. (2020) Die Feststellung einer epidemischen Lage von nationaler Tragweite - ein Experiment parlamentarischer Handlungsformen, Medizinrecbt, 38(9), pp. 741-744.

Hourson, S. (2020) Aux confins du confinement, Droit administratif, 5, p. 3.

Jackson, V.C. (2004) Proconstitutional behavior, political actors, and independent courts: A comment on Geoffrey Stone's paper, International Journal of Constitutional Law, 2(2), pp. 368-369.

Janik, M. (2015) Płaszcyyzny dzৃałania organów poligi sanitarnej w sferze nadzoru sanitarnego i epidemiologicznego. Studium administracyjnoprawne (Katowice), p. 105.

Miaskowska-Daszkiewicz, K. (2017) Prawne instrumenty wspierające bezpieczeństwo epidemiczne biorców ludzkich komórek, tkanek i narządów, Studia Prawnicze KUL 3, pp. 69-71.

Pałka, K. (2018) Świadczenia zdrowotne związane z chorobami zakaźnymi, In: Safjan M. \& Bosek, L. (eds.) System Prawa Medycznego, vol 2 (Warsaw: C.H. Beck), pp. 601-624.

Prokop, K. (2005) Stany nadrayyczajne w Konstytuci Rzecrypospolitej Polskiej z dnia 2 kwietnia 1997 r. (Białystok: Temida).

Radziewicz, P. (2019) In P. Tuleja (ed.) Konstytucja Rzeczypospolitej Polskiej. Komentarz (Warsaw: Wolters Kluwer), p. 654.

Schmitt, F. (2020) Die Verfassungswidrigkeit der landesweiten Ausgangsverbote, Neue Juristische Wochenschrift, (23), pp. 1626-1631.

Sizaire, V. (2020) Un colosse aux pieds d'argile. Les fondements juridiques fragiles de l'urgence sanitaire, La Revue des droits de l'homme, 2, pp. 1-10.

Steinborn, S. (2016) In: Safjan M., Bosek L. (eds.) Konstytucja Rzecrypospolitej Polskiej. Komentarz, vol. II, (Warsaw: C.H. Beck), p. 1626.

Wiśniewski, L. (1997) Stany nadzwyczajne w projekcie nowej Konstytucji RP, In: Jasudowicz, T. (ed.) Prawa cztowieka w sytuacjach nadzrnyczajnych ze szcrególnym uwaglednieniem prawa i praktyki polskiej (Torun: "Dom Organizatora" TNOiK), p. 152.

Wojtyczek, K. (1999) Granice ingerencii ustawodawczej w sfere praw ç̨towieka w Konstytucji RP (Kraków: Zakamycze), pp. 250-251.

Wołpiuk, W.J. (2002) Państwo wobec szczególnych zagrożeń. Komentarz do uybranych przepisón Konstytucji Rzecsypospolitej Polskiej z dnia 2 kwietnia 1997 r. (Warszawa: Wydawnictwo Naukowe "Scholar"), p. 101. 
